\title{
Hubungan antara Perilaku Gizi dan Perilaku Hidup Bersih dan Sehat (PHBS) dengan Status Gizi Baduta Di Kabupaten Cirebon
}

\section{Association between Nutritional Behavior and Clean and Healthy Lifestyle Behavior (CHLB) with Nutritional Status of Under Two-Years Infants in Cirebon Regency}

Winda Puspita Yuniar, Ali Khomsan", Mira Dewi, Karina Rahmadia Ekawidyani, Anna Vipta Resti Mauludyani

ABSTRAK

Latar belakang: Kabupaten Cirebon merupakan salah satu daerah prioritas yang menjadi lokus dalam upaya percepatan penurunan stunting pada tahun 2018.

Tujuan: Penelitian ini bertujuan untuk menganalisis hubungan antara pola asuh makan dengan asupan zat gizi baduta serta hubungan antara perilaku gizi dan perilaku hidup bersih dan sehat dengan status gizi baduta di Kabupaten Cirebon.

Metode: Penelitian ini menggunakan desain studi cross-sectional dengan menggunakan data sekunder dari penelitian sebelumnya yang dilakukan pada dua lokasi yang sama di Kabupaten Cirebon. Proses pengolahan data dilakukan pada bulan November hingga Desember 2019. Subjek yang terlibat adalah 70 orang ibu baduta yang memiliki bayi berusia 0-24 bulan. Analisis hubungan antar variabel menggunakan uji Rank Spearman.

Hasil: Hasil uji korelasi menunjukkan bahwa tidak terdapat hubungan yang signifikan $(p>0,05)$ antara pola asuh makan dengan asupan zat gizi. Selain itu, perilaku gizi ibu juga tidak memilki hubungan yang signifikan $(p>0,05)$ dengan status gizi. Penelitian ini menemukan bahwa terdapat hubungan yang signifikan antara perilaku hidup bersih dan sehat pada indikator lingkungan rumah bebas asap rokok terhadap status gizi baduta.

Kesimpulan: Ketidakseimbangan antara pengetahuan dengan faktor sosio-ekonomi penghasilan dapat mengakibatkan terjadinya ketimpangan dalam penerapan pola asuh makan, perilaku gizi, dan PHBS terhadap status gizi baduta. Oleh karena itu, diperlukan sistem monitoring dan evaluasi secara kontinu untuk memastikan bahwa program percepatan stunting berjalan secara efektif dan efisien.

Kata kunci: asupan zat gizi, perilaku gizi, PHBS, pola asuh makan, stunting

\section{ABSTRACT}

Background: Cirebon Regency is one of the priority areas that becomes the locus in efforts to accelerate the reduction of stunting in 2018.

Objective: This study aimed to analyze the relationship between feeding parenting pattern with nutrient intake of under two-years infants and the relationship between nutritional behavior and clean and healthy lifestyle behavior (CHLB) with nutritional status of under two-years infants in Cirebon Regency.

Methods: This study used a cross-sectional study design using secondary data from previous studies conducted at the same two locations in Cirebon Regency. The data processing was carried out in November to December 2019. The subjects were 70 mothers who had infants aged 0-24 months. Analysis of the relationship between variables using the Rank Spearman test.

Results: The results of the correlation test showed that there was no significant relationship ( $p>0.05)$ between feeding parenting pattern with nutritional intake. In addition, maternal nutritional behavior also did not have a significant relationship ( $p>0.05$ ) with nutritional status. This study found that there was a significant relationship between clean and healthy living behavior on the indicators of a smoke-free home environment with the nutritional status using HAZ index.

Conclusion: Imbalance between knowledge and socio-economic factors of income can lead to inequality in the application of feeding parenting pattern, nutritional behavior, and CHLB to the nutritional status of under two years. Therefore, a continuous monitoring and evaluation system is needed to ensure that the stunting acceleration program runs effectively and efficiently.

Keywords: nutrient intake, nutritional behavior, CHLB, feeding parenting pattern, stunting 


\author{
*Koresponden : \\ Ali Khomsan \\ erlangga259@yahoo.com \\ Departemen Gizi Masyarakat, Fakultas Ekologi Manusia, IPB University, Jl. Lingkar Kampus, Kampus IPB, Babakan, Kec. \\ Dramaga, Bogor, Jawa Barat, Indonesia
}

\section{PENDAHULUAN}

Isu terkait gizi yang sedang populer dalam beberapa tahun terakhir yaitu kejadian stunting. Stunting (tengkes) didefinisikan sebagai keadaan dimana tubuh anak memiliki tinggi atau panjang badan lebih pendek dari normal pada usianya. Stunting tergolong ke dalam masalah gizi kronik yang dalam jangka waktu panjang dapat menyebabkan terganggunya perkembangan fisik dan koginitif bayi secara normal. Kondisi tersebut dicerminkan oleh nilai Z-score yang kurang dari -2 SD (Standar Deviasi) dan kurang dari -3 $\mathrm{SD}^{1}$. Hasil Riskesdas (2018) mengungkapkan bahwa proporsi balita sangat pendek dan pendek pada tahun 2018 berkisar pada angka 11,5\% dan 19,3\% dengan indikator pengukuran berupa indeks tinggi badan menurut umur $(\mathrm{TB} / \mathrm{U})^{2}$. Secara global, World Health Organization (WHO) menyatakan bahwa Indonesia merupakan negara ketiga dengan prevalensi stunting teratas di region Asia Tenggara dengan rata-rata prevalensi balita stunting mencapai $36,4 \%$ pada tahun 2005-2017 ${ }^{1}$.

Malnutrisi dapat disebabkan oleh faktor-faktor yang saling berkaitan seperti faktor sosial ekonomi, budaya, pendidikan, dan lingkungan. Berdasarkan kerangka pikir UNICEF (1990), penyebab tidak langsung yang dapat mempengaruhi asupan gizi dan infeksi pada bayi adalah pola asuh. Pola asuh yang terbentuk dalam suatu keluarga bergantung pada pengetahuan yang dimiliki oleh orang tua dalam keluarga tersebut. Pengetahuan gizi yang baik juga akan menjadi dasar bagi pembentukan kebiasaan dan perilaku gizi yang baik dalam lingkup rumah tangga. Pengetahuan gizi juga akan mempengaruhi perilaku ibu dalam menjaga kebersihan diri dan lingkungan tempat tinggalnya. Perilaku mengenai kebersihan diri dan makanan dapat dipengaruhi oleh banyak faktor, seperti kepercayaan, mitos, atau tradisi yang bersifat turun-temurun. Penerapan perilaku hidup bersih dan sehat (PHBS) dalam kehidupan sehari-hari di lingkungan rumah tangga dapat menurunkan risiko terjadinya infeksi atau penyakit baik pada ibu maupun bayinya. Oleh sebab itu, PHBS dapat dijadikan sebagai salah satu faktor pendukung dalam rangka tercapainya indikator kesehatan dalam lingkungan masyarakat ${ }^{3}$.

Penelitian ini bertujuan untuk menganalisis hubungan antara pola asuh makan dengan asupan zat gizi, serta hubungan antara perilaku gizi dan perilaku hidup bersih dan sehat dengan status gizi baduta di Kabupaten Cirebon. Penelitian mengenai stunting sudah banyak dilakukan di Indonesia, khususnya di daerah lokus yang menjadi prioritas dalam penanganan stunting. Hasil penelitian ini dapat dijadikan sebagai gambaran bagi penyelenggara kebijakan dalam mempertimbangkan pemberian program yang akan ditetapkan untuk menanggulangi masalah stunting di Indonesia.

\section{METODE}

Desain penelitian yang digunakan dalam penelitian ini adalah cross-sectional dengan melakukan pengolahan data sekunder Khomsan et al. (2019) ${ }^{4}$. Pengambilan data dilakukan pada bulan Juli sampai Agustus 2019 lalu data diolah pada bulan November hingga Desember 2019. Lokasi penelitian yang dipilih bertempat di Kabupaten Cirebon yaitu Desa Sibubut dan Desa Kedungdalem. Kabupaten Cirebon dipilih karena memiliki prevalensi stunting tinggi $(42,5 \%$ pada tahun 2013), kemudahan akses, serta perolehan izin penelitian dari pemerintah daerah setempat. Cakupan populasi dalam studi ini yaitu meliputi seluruh bayi atau anak berusia 0-23 bulan yang tercatat dalam laporan kader dari masing-masing posyandu di desa. Penentuan jumlah subjek minimum mengacu pada Lemeshow et al. (1997) dan disesuaikan dengan kriteria inklusi dan eksklusi ${ }^{5}$. Kriteria inklusi yang ditetapkan yaitu ibu baduta yang terdaftar di posyandu setempat, yaitu : 1) mempunyai anak usia 0-23 bulan dan tinggal bersama ibunya, dan 2) ibu baduta berusia 18-42 tahun. Sementara itu, kriteria eksklusi penelitian ini antara lain : 1) ibu menderita penyakit kronis, 2) baduta yang diamati merupakan anak kembar, 3) baduta mengalami cacat bawaan, dan 4) baduta menderita penyakit kronis. Sebanyak 70 orang menjadi subjek dari penelitian ini yang terdiri atas ibu dan badutanya.

Data-data sekunder yang dikumpulkan dalam studi ini meliputi data karakteristik sosio-ekonomi keluarga, karakteristik subjek dan baduta, pola asuh makan, asupan gizi, perilaku gizi dan PHBS pada tatanan rumah tangga. Karakteristik sosio-ekonomi meliputi tingkat pendidikan subjek, pekerjaan, penghasilan rumah tangga, serta pengeluaran rumah tangga untuk kebutuhan pangan dan non-pangan. Karakteristik subjek meliputi usia, status gizi, dan usia hamil pertama. Sementara itu, karakter baduta yang diamati adalah usia, jenis kelamin, berat badan lahir, dan berat dan panjang saat ini. Pola asuh makan diidentifikasi menggunakan indikator praktik pemberian makan dan sikap ibu dalam pemberian makan. Asupan zat gizi dan kebiasaan makan diperoleh dengan menganalisis hasil Recall $2 \times 24 h$ dan Food Frequency Questionnaire. Perilaku gizi yang dimaksud meliputi pemberian imunisasi dan IMD (Inisiasi Menyusui Dini), pemberian ASI dan MP-ASI serta mengenai tabu makanan. Indikator PHBS yang digunakan dalam penelitian ini antara lain proses persalinan dibantu oleh tenaga medis, penimbangan rutin ke posyandu, perilaku cuci tangan, penggunaan air bersih dan jamban layak, pembersihan larva nyamuk rutin, dan lingkungan rumah bebas asap rokok.

Masing-masing indikator dalam karakteristik sosio-ekonomi keluarga juga dikategorikan ke dalam kelompok-kelompok. Tingkat pendidikan dikategorikan menjadi tidak sekolah/tidak tamat sekolah, $\mathrm{SD} / \mathrm{MI} /$ sederajat, $\quad \mathrm{SMP} / \mathrm{MTs} /$ sederajat, dan 
SMA/SMK/sederajat, serta lulusan diploma (D3). Pekerjaan diklasifikasikan berdasarkan Kemenkes RI (2013), yaitu tidak bekerja, petani, pedagang, buruh tani, buruh non-tani, PNS/ABRI/polisi, jasa, IRT (Ibu Rumah Tangga), dan lainnya ${ }^{6}$. Indikator penghasilan rumah tangga yang digunakan adalah Upah Minimum Provinsi Jawa Barat. Pengeluaran rumah tangga digolongkan ke dalam dua kelompok, yaitu pengeluaran pangan dan non-pangan.

Asupan zat gizi menurut Recall $2 \times 24 \mathrm{~h}$ kemudian dikategorikan berdasarkan WNPG (2012) untuk mengetahui asupan tergolong ke dalam kurang, cukup, atau lebih ${ }^{7}$. Sistem skoring dilakukan untuk menggolongkan pola asuh makan, perilaku gizi, dan PHBS ke dalam kategori kurang, sedang, dan baik dengan skor berturut-turut $<60 \%, 60-80 \%$, dan $>80 \%$ jawaban benar ${ }^{8}$. Status gizi baduta diperoleh dengan menggunakan alat analisis berupa WHO Anthro 3.2.2. Indeks status gizi yang digunakan untuk mengidentifikasi status gizi baduta berupa $\mathrm{BB} / \mathrm{U}$ dan $\mathrm{TB} / \mathrm{U}$ dan dikategorikan sesuai Kemenkes RI (2020) ${ }^{9}$.

\section{HASIL DAN PEMBAHASAN}

Gambaran karakteristik subjek dan baduta disajikan pada Tabel 1. Proporsi baduta laki-laki dan perempuan yaitu sebesar $51,4 \%$ dan $48,6 \%$. Sebagian besar baduta $(55,7 \%)$ berusia $12-24$ bulan dan yang paling sedikit $(10,0 \%)$ berusia 0-6 bulan. Lebih dari $90,0 \%$ baduta lahir dengan berat badan normal dan sisanya lahir dengan berat badan lahir rendah (BBLR) yaitu $<2,5$ $\mathrm{kg}$.

Setengah dari subjek tergolong gizi lebih dan sekitar 2,9\% subjek berstatus gizi kurang. Pendidikan subjek sebagian besar lulusan SD/MI/Sederajat dan hanya ada satu subjek yang menamatkan pendidikan tinggi (diploma). Tiga dari empat subjek merupakan seorang Ibu Rumah Tangga (IRT). Sebagian kecil lainnya hidup sebagai petani, buruh tani, dan pedagang.

Sebagian besar rumah tangga mendapatkan penghasilan di atas Upah Minimal Provinsi Jawa Barat dengan rata-rata pendapatan Rp 3614503 per bulan. Terdapat 17 keluarga $(24,3 \%)$ mendapatkan penghasilan di bawah UMP Jawa Barat, yaitu dengan rata-rata pendapatan per bulan sebesar Rp 1305 564. Secara keseluruhan, upah terkecil dari total subjek yaitu Rp 1 000000 sedangkan upah terbesar yaitu Rp 15000000 . Rata-rata penghasilan seluruh subjek juga berada di atas UMP Jawa Barat yaitu sebesar Rp 3053760.

Pengeluaran rumah tangga dari 70 subjek sebagian besar digunakan untuk kebutuhan pangan. Pengeluaran terbesar untuk kebutuhan pangan digunakan untuk pembelian jajanan yaitu sebesar Rp 416 247 per bulan atau sekitar $13,6 \%$ dari pendapatan ratarata subjek. Pengeluaran terbanyak kedua digunakan untuk pembelian lauk pauk sebesar Rp 391057 (12,8\%) dan makanan pokok, khususnya beras, sebesar Rp 267 $230(8,8 \%)$.

Pengeluaran rumah tangga untuk kebutuhan non-pangan rata-rata sebesar $36,8 \%$ atau sekitar Rp 1 123060 dalam satu bulan. Pengeluaran terbanyak adalah untuk kepentingan pendidikan anak yang meliputi uang saku dan biaya SPP, yaitu sebesar Rp 252
558 (8,3\%). Pengeluaran terbanyak kedua setelah untuk pendidikan adalah untuk pembelian rokok yaitu Rp 239 $949(7,9 \%)$. Alokasi pembelanjaan paling kecil digunakan untuk kesehatan atau pengobatan yaitu Rp 23224 $(0,8 \%)$.

Status gizi baduta diperoleh dengan cara mengkalkulasi data berat badan dan tinggi atau panjang badan saat ini dengan data usia baduta. Hasil perhitungan status gizi baduta disajikan pada gambar 1 . Gambar 1 menunjukkan bahwa sebagian besar baduta berstatus gizi normal menurut indeks BB/U dan sekitar $11,4 \%$ baduta berstatus gizi underweight. Berdasarkan indeks TB/U, ditemukan $8,6 \%$ baduta mengalami stunting dan sisanya normal.

Tabel 1 Karakteristik baduta dan subjek

\begin{tabular}{|c|c|c|}
\hline Karakteristik & $\mathrm{n}$ & $\%$ \\
\hline \multicolumn{3}{|l|}{ Jenis kelamin baduta } \\
\hline \multirow[t]{2}{*}{ Laki-laki } & 3 & 51,4 \\
\hline & 6 & \\
\hline \multirow[t]{2}{*}{ Perempuan } & 3 & 48,6 \\
\hline & 4 & \\
\hline \multicolumn{3}{|l|}{ Usia (bulan) } \\
\hline $0-6$ & 7 & 10,0 \\
\hline \multirow[t]{2}{*}{$7-11$} & 2 & 34,3 \\
\hline & 4 & \\
\hline \multirow[t]{2}{*}{$12-24$} & 3 & 55,7 \\
\hline & 9 & \\
\hline \multicolumn{3}{|l|}{ Berat badan lahir } \\
\hline$<2,5 \mathrm{~kg}$ & 2 & 2,9 \\
\hline \multirow[t]{2}{*}{$\geq 2,5 \mathrm{~kg}$} & 6 & 97,1 \\
\hline & 8 & \\
\hline \multicolumn{3}{|l|}{ Status gizi ibu } \\
\hline \multirow[t]{2}{*}{ Gizi lebih } & 3 & 50,0 \\
\hline & 5 & \\
\hline \multirow[t]{2}{*}{ Normal } & 3 & 47,1 \\
\hline & 3 & \\
\hline Gizi kurang & 2 & 2,9 \\
\hline \multicolumn{3}{|l|}{ Pendidikan Ibu } \\
\hline $\begin{array}{l}\text { Tidak sekolah/Tidak tamat } \\
\text { sekolah }\end{array}$ & 7 & 10,0 \\
\hline \multirow[t]{2}{*}{$\mathrm{SD} / \mathrm{MI} /$ sederajat } & 4 & 62,9 \\
\hline & 4 & \\
\hline \multirow[t]{2}{*}{ SMP/MTs/sederajat } & 1 & 15,7 \\
\hline & 1 & \\
\hline SMA/SMK/sederajat & 6 & 8,6 \\
\hline D3 & 1 & 1,4 \\
\hline \multicolumn{3}{|l|}{ Pekerjaan Ibu } \\
\hline Petani & 2 & 2,9 \\
\hline Pedagang & 4 & 8,6 \\
\hline Buruh tani & 6 & 8,6 \\
\hline \multirow[t]{2}{*}{ IRT (Ibu Rumah Tangga) } & & 75,7 \\
\hline & 9 & \\
\hline
\end{tabular}

Salah satu faktor yang mempengaruhi asupan zat gizi pada golden period adalah pola asuh makan. Karyadi (1985) dalam Martianto et al. (2011) menyatakan bahwa pola asuh makan merupakan wujud 
praktik pengasuhan yang diberikan oleh ibu kepada baduta terkait dengan pemberian makan dilihat dari situasi dan cara pemberian makannya ${ }^{10}$. Secara umum, sebagian besar subjek (98,6\%) menyatakan bahwa sehari-hari baduta diasuh oleh ibu dan jadwal makannya ditentukan oleh ibu. Seluruh subjek juga menyatakan bahwa biasanya yang menyiapkan makanan baduta dan mengatur jadwal makan baduta adalah ibu. Sebesar $84,2 \%$ baduta sudah memiliki jadwal makan yang teratur dan $52,9 \%$ baduta tidak mengalami problema sulit makan.

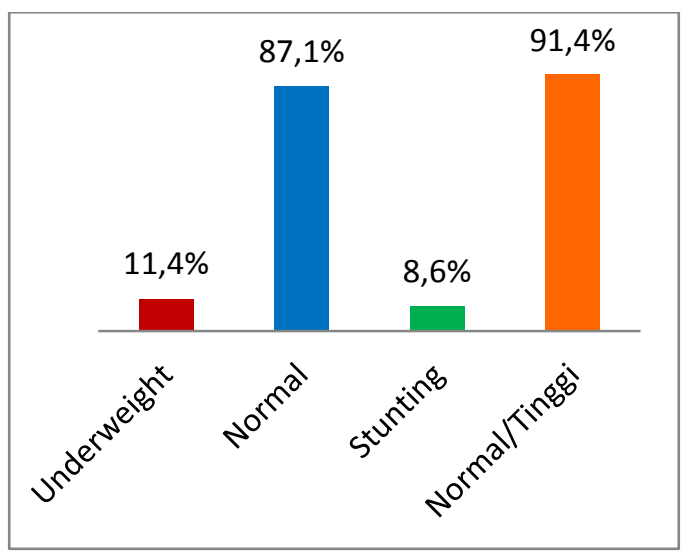

Gambar 1 Diagram sebaran status gizi baduta berdasarkan indeks $\mathrm{BB} / \mathrm{U}$ dan $\mathrm{TB} / \mathrm{U}$

Penelitian ini juga menemukan bahwa praktik pemberian makan yang dilakukan oleh ibu sudah cukup baik dalam hal pengasuhan, penyiapan dan pengaturan jadwal makan, serta situasi yang dibangun saat memberikan makan kepada anak. Praktik pemberian makan yang baik dapat meningkatkan kualitas konsumsi makanan yang pada akhirnya akan berdampak pada asupan zat gizi yang diperoleh oleh anak. Asupan zat gizi merupakan faktor determinan yang secara langsung dapat mempengaruhi status gizi anak ${ }^{11}$.

Situasi pemberian makan yang dibangun oleh ibu ketika memberi makan kepada anak juga menjadi komponen penting dalam praktik pemberian makan. Dalam penelitian ini, seluruh subjek sudah menerapkan situsi makan kepada anak dengan benar yaitu diusahakan disiplin dan tidak sambil bermain $(27,1 \%)$ atau dengan sambil bermain di sekitar rumah $(72,9 \%)$. Proporsi mengenai cara pengenalan makanan kepada anak hampir sama, antara diberikan tersendiri $(51,4 \%)$ atau diberikan dengan makanan yang sudah dikenal sebelumnya $(48,6 \%)$.

Sebagian besar subjek juga sudah mengetahui bagaimana sikap yang benar ketika anak menolak makanan tertentu,yaitu dengan cara membuat inovasi makanan baru dilakukan oleh 24 orang (34,3\%) atau tetap diberikan dalam waktu yang berbeda dilakukan oleh 35 orang $(50,0 \%)$. Sekitar 45 subjek $(64,3 \%)$ juga menerapkan sikap untuk membujuk atau merayu anak ketika anak sedang sulit makan. Hampir $83,0 \%$ subjek juga menyatakan bahwa sikap subjek ketika anak menghabiskan makanannya yaitu dengan memberikan pujian kepada anak. Hasil pengkategorian pola asuh makan menunjukkan bahwa sebanyak $87,1 \%$ ibu baduta sudah menerapkan pola asuh makan yang baik kepada anaknya sedangkan sisanya tergolong ke dalam kategori sedang. Hasil penelitian ini sejalan dengan penelitian Widyaningsih et al.(2018) yang dilakukan di kabupaten prioritas stunting yaitu Kabupaten Klaten, Jawa Tengah. Dalam penelitian tersebut, diketahui bahwa pola asuh makan memiliki hubungan yang signifikan dalam kejadian stunting. Akan tetapi, meskipun menjadi daerah lokus stunting, sebagian besar penduduknya sudah menerapkan pola asuh makan yang baik terhadap balitanya $^{12}$

Perilaku gizi merupakan bagian dari perilaku kesehatan yang dinyatakan sebagai suatu respon organisme atau individu terhadap stimulus berupa sakit atau penyakit dan dikaitkan dengan asupan (makanan dan minuman) ${ }^{13}$. Dalam penelitian ini, perilaku gizi yang diamati meliputi Inisiasi Menyusui Dini (IMD), pemberian kolustrum, imunisasi, ASI eksklusif, MP-ASI, dan kualitas konsumsi pangan yang ditentukan berdasarkan keragaman pangan. Data sebaran perilaku gizi ibu disajikan pada Tabel 2.

Tabel 2 Sebaran data perilaku gizi ibu baduta

\begin{tabular}{lrr}
\multicolumn{1}{c}{ Perilaku Gizi lbu Baduta } & $\mathrm{n}$ & $\%$ \\
\hline Melakukan Inisiasi Menyusui Dini (IMD) & 31 & 44,9 \\
Memberikan kolustrum & 45 & 65,2 \\
Memberikan imunisasi & 3 & 4,3 \\
Memberikan ASI eksklusif & 6 & 8,6 \\
Pemberian makanan/minuman non-ASI & & \\
$\quad$ Usia $<6$ bulan & 64 & 91,4 \\
$\quad$ Usia 6 bulan & 6 & 8,6 \\
Pemberian MP-ASI & & \\
$\quad$ Usia $<6$ bulan & 35 & 50,0 \\
$\quad$ Usia 6 bulan & 30 & 42,9 \\
$\quad$ Usia $>6$ bulan & 5 & 7,1 \\
Mengonsumsi daging $\geq 3$ dalam seminggu & 25 & 36,2 \\
Mengonsumsi telur $\geq 4$ dalam seminggu & 13 & 18,8 \\
Mengonsumsi ikan $\geq 4$ dalam seminggu & 11 & 15,9 \\
Mengonsumsi kacang-kacangan $\geq 3$ dalam seminggu & 34 \\
Mengonsumsi sayuran hijau atau orens $\geq 4$ dalam seminggu & 35 \\
Mengonsumsi buah $\geq 3$ dalam seminggu & 33 & 50,3 \\
\hline
\end{tabular}


Berdasarkan Tabel 2 diketahui bahwa rata-rata perilaku gizi ibu yang diterapkan dengan benar berada pada rentang 4,3-65,2\% dari total subjek. Hasil tersebut kemudian dikategorikan menurut kualitasnya, yaitu baik, sedang, dan kurang. Penelitian ini menemukan bahwa perilaku gizi dari keseluruhan subjek tidak ada yang tergolong ke dalam perilaku gizi baik. Proporsi subjek dengan perilaku gizi kategori sedang dan kurang juga tidak jauh berbeda yaitu berturut-turut sebesar 52,5\% dan $47,8 \%$. Terbentuknya perilaku gizi dipengaruhi oleh banyak faktor baik internal ataupun eksternal. Penelitian yang dilakukan oleh Blaney et al. (2015) menemukan bahwa perilaku gizi terkait pemberian makan makan

Gambar 2 memperlihatkan bahan pangan yang paling sering dikonsumsi oleh baduta dari kelompok makanan pokok, protein hewani, protein nabati, sayur, buah, dan jajanan. Nasi, susu, tahu, wortel, jeruk, dan gorengan merupakan bahan pangan yang paling sering dikonsumsi dari keseluruhan baduta. Sebagian besar bahan pangan pada Gambar 2 dikonsumsi sebanyak 1-6 kali dalam seminggu atau paling tidak dikonsumsi sekali dalam sehari.

Nasi merupakan bahan pangan utama yang hampir selalu ada dalam setiap kali makan. Sebagian besar frekuensi konsumsi nasi sebanyak 1-2 kali sehari dan lebih dari 3 kali dalam sehari. Susu merupakan sumber protein hewani yang paling sering dikonsumsi oleh sebagian besar baduta. Namun setengah dari total baduta tidak biasa mengonsumsi susu dan hanya 56,0\% baduta yang mengonsumsi susu setidaknya satu kali dalam seminggu. kepada bayi berusia lebih dari 6 bulan berkaitan dengan pengetahuan, persepsi, kepercayaan, sikap dan kemampuan ibu, pelayan kesehatan, serta keadaan lingkungan di sekitar rumah ${ }^{14}$.

Kebiasaan makan merupakan preferensi pilihan makanan yang dimiliki individu yang telah dilakukan dalam jangka waktu yang lama. Keluarga merupakan subjek penting yang berperan dalam memperkenalkan berbagai jenis makanan yang sehat dan menjadi contoh dalam memilih makanan bergizi dan beragam $^{15}$. Data kebiasaan makan baduta dilihat dari keberagaman bahan pangan yang dikonsumsi disajikan pada Gambar 2.

Sumber protein nabati yang paling banyak dikonsumsi oleh baduta adalah tahu dengan frekuensi konsumsi terbanyak adalah 1-6 kali per minggu. Dari segi ekonomi, tahu merupakan bahan pangan yang cukup terjangkau dan mudah dijumpai oleh penduduk sehingga proporsi konsumsi tahu lebih banyak dibandingkan protein nabati yang lain.

Jenis sayur yang paling sering dikonsumsi oleh baduta adalah wortel dengan frekuensi konsumsi terbanyak kedua yaitu 1 hingga 2 kali dalam sehari. Namun, masih terdapat $16 \%$ dari total baduta yang tidak mengonsumsi sayur sama sekali dalam satu minggu. Frekuensi konsumsi buah, khususnya jeruk, lebih tinggi daripada konsumsi sayuran. Sebanyak $7,1 \%$ baduta memiliki kebiasaan mengonsumsi buah jeruk 1 hingga 2 kali dalam sehari dan $84,6 \%$ baduta mengonsumsinya paling tidak satu kali dalam sehari.

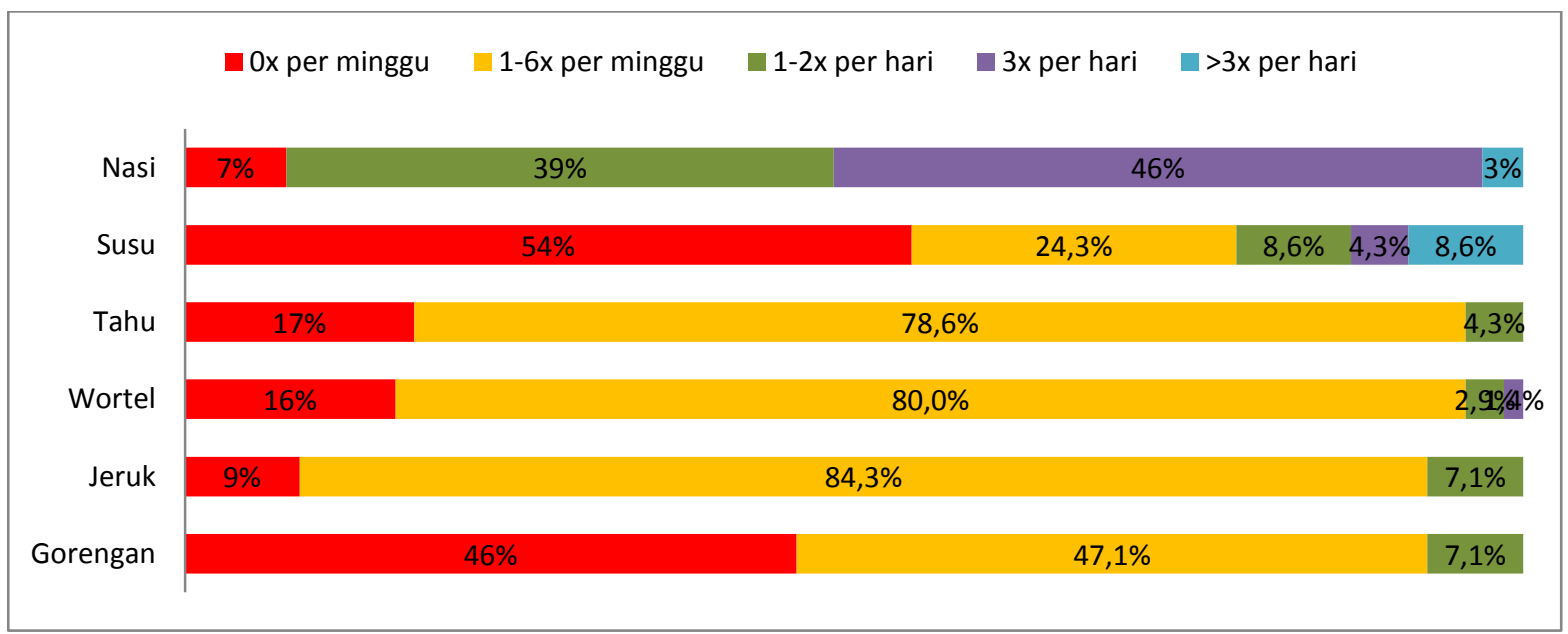

Gambar 2 Diagram kebiasaan makan baduta berdasarkan frekuensi makan

Kebiasaan makan juga dapat dipengaruhi oleh budaya yang ada di masyarakat. Budaya yang ada di masyarakat sering dikaitkan dengan hal-hal mistik atau supranatural yang apabila seseorang melanggar suatu pantangan, maka orang tersebut akan mendapatkan hukuman atas perbuatannya ${ }^{16}$. Namun, hal tersebut dapat menimbulkan dampak yang kurang baik pada asupan zat gizi yang diterima anak. Tabu makanan dapat menjadi salah satu faktor pembatas untuk memperoleh asupan zat gizi yang cukup baik secara kualitas maupun kuantitas. Tabu makanan pada penelitian ini berasal dari kelompok makanan pokok, minuman, jajanan, dan pelengkap. Tabu makanan tersebut dipercaya oleh 6 orang $(8,6 \%)$ dari 70 subjek. Beberapa alasan pada tabu makanan yang sudah benar diantaranya konsumsi permen yang dapat menyebabkan karies gigi dan sambal yang belum waktunya diberikan kepada bayi karena sistem pencernaannya belum siap.

Kualitas konsumsi pangan berkaitan erat dengan kuantitas konsumsi pangan. Pada masa golden period, jumlah pangan yang dikonsumsi harus memiliki proporsi yang tepat sesuai dengan kebutuhan asupan zat gizi 
baduta. Dalam penelitian ini, asupan zat gizi baduta dihitung dari tingkat kecukupan zat gizi makronya, yaitu energi, protein, lemak, dan karbohidrat. Diagram ratarata tingkat kecukupan zat gizi baduta disajikan pada Gambar 3.

Dalam penelitian ini, rata-rata TKE dan TKL, termasuk ke dalam kategori cukup. Sementara itu, ratarata TKP dan TKKH baduta sudah tergolong ke dalam kategori lebih karena nilainya lebih besar dari $110 \%{ }^{7}$.

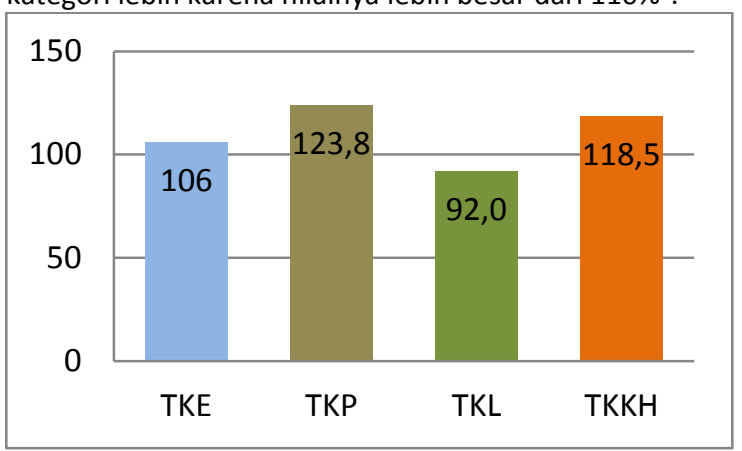

Gambar 3 Rata-rata tingkat kecukupan asupan zat gizi baduta

Sementara itu, penelitian ini juga menemukan bahwa proporsi TKE kategori kurang, cukup, dan lebih tidak jauh berbeda satu sama lain, yaitu berturut-turut $34,4 \%, 31,3 \%$, dan 34,4\%. Sementara itu, sebagian besar baduta memiliki TKP yang tergolong ke dalam kategori lebih, yaitu sebesar 46,9\%. TKP dalam kategori cukup dan kurang memiliki proporsi yang tidak berbeda jauh yaitu $28,1 \%$ dan $25,0 \%$. TKL sebagian besar berada pada kategori kurang, yaitu sebesar $37,5 \%$ sedangkan yang termasuk ke dalam kategori cukup hanya $28,1 \%$. Di sisi lain, proporsi terbanyak TKKH berada pada kategori lebih yaitu sebesar $37,5 \%$ dan yang terkategori cukup hanya $26,6 \%$. Asupan zat gizi baduta dilihat dari tingkat kecukupan zat gizi makro secara umum sudah cukup baik. Akan tetapi, sepertiga dari jumlah subjek berada dalam kategori kurang pada TKE, TKL, dan TKKH. Ketidakcukupan asupan tersebut dapat meliputi beberapa hal diantaranya pemberian MP-ASI yang jarang, pemberian makan yang tidak memadai saat dan pasca sakit, konsistensi makanan yang terlalu encer, kuantitas makanan yang tidak cukup, atau pemberian makan yang tidak responsif. Sub-elemen tersebut harus menjadi fokus dalam pemberian pendidikan gizi yang diberikan dalam penanganan masalah ketidakcukupan asupan zat gizi pada baduta ${ }^{17}$.

PHBS (Perilaku Hidup Bersih dan Sehat) diartikan sebagai kebiasaan individu untuk hidup sehat yang diterapkan dalam kehidupan sehari-hari dan menghindari kebiasaan buruk yang dapat mengganggu kesehatan. Hasil penelitian ini mengungkapkan bahwa seluruh subjek sudah menggunakan fasilitas pelayanan kesehatan berupa proses persalinan yang dibantu oleh tenaga medis. Namun, penimbangan berat badan rutin setiap bulan hanya dilakukan oleh 20 subjek $(28,6 \%)$ dari total keseluruhan subjek.

Tabel 3 Hasil uji korelasi variabel pola asuh makan dengan tingkat kecukupan zat gizi

\begin{tabular}{|c|c|c|c|c|c|c|c|c|}
\hline \multirow{3}{*}{ Pola Asuh Makan } & \multicolumn{8}{|c|}{ Asupan Zat Gizi } \\
\hline & \multicolumn{2}{|c|}{ TKE } & \multicolumn{2}{|c|}{ TKP } & \multicolumn{2}{|c|}{ TKL } & \multicolumn{2}{|c|}{ TKKH } \\
\hline & $r$ & $\begin{array}{c}p- \\
\text { value }\end{array}$ & $r$ & $\begin{array}{c}p- \\
\text { value }\end{array}$ & $r$ & $\begin{array}{c}p- \\
\text { value }\end{array}$ & $r$ & $\begin{array}{c}p- \\
\text { value }\end{array}$ \\
\hline Sehari-hari anak diasuh oleh ibu & -0.015 & 0.903 & 0.033 & 0.788 & -0.054 & 0.659 & 0.009 & 0.941 \\
\hline $\begin{array}{l}\text { Ibu biasanya menyiapkan } \\
\text { makanan anak }\end{array}$ & -0.126 & 0.297 & -0.172 & 0.155 & -0.100 & 0.409 & -0.185 & 0.125 \\
\hline Ibu menentukan jadwal makan anak & -0.119 & 0.325 & -0.143 & 0.238 & -0.029 & 0.813 & -0.194 & 0.108 \\
\hline Jadwal makan anak teratur & 0.064 & 0.598 & 0.093 & 0.443 & -0.092 & 0.447 & 0.127 & 0.294 \\
\hline Situasi saat memberi makan anak & 0.128 & 0.291 & 0.145 & 0.232 & 0.067 & 0.583 & 0.133 & 0.273 \\
\hline $\begin{array}{l}\text { Sikap ibu jika anak menolak makanan } \\
\text { tertentu }\end{array}$ & -0.113 & 0.353 & -0.057 & 0.637 & -0.118 & 0.332 & -0.096 & 0.428 \\
\hline Sikap ibu jika anak sulit makan & 0.089 & 0.463 & 0.131 & 0.280 & -0.022 & 0.854 & 0.098 & 0.420 \\
\hline $\begin{array}{l}\text { Sikap ibu jika anak menghabiskan } \\
\text { makanannya }\end{array}$ & -0.094 & 0.440 & -0.070 & 0.563 & -0.105 & 0.387 & 0.007 & 0.957 \\
\hline
\end{tabular}

Higiene dalam melakukan aktifitas yang berkaitan dengan baduta masih kurang karena hanya sekitar 34,3\% dari seluruh subjek yang mencuci tangan sebelum dan sesudah memberikan ASI. Namun, sebagian besar subjek sudah menerapkan cuci tangan setiap keluar dari kamar mandi (74,3\%) dan setiap akan menjamah makanan (80,0\%). Di sisi lain, hanya $55,7 \%$ dari subjek yang menggunakan sabun dan air mengalir sebagai media untuk mencuci tangan.

Indikator lain dalam penerapan PHBS lingkup rumah tangga yaitu penggunaan air bersih, WC laterine, pembasmian larva nyamuk, dan penggunaan rokok. Dalam penelitian ini, ditemukan bahwa seluruh subjek sudah menggunakan air bersih untuk dikonsumsi dan sebanyak $68,6 \%$ subjek telah menggunakan WC laterine di rumah. Pembasmian larva nyamuk sekali seminggu hanya dilakukan oleh $27,1 \%$ dari total subjek. Sementara itu, hanya $31,4 \%$ subjek yang memiliki lingkungan rumah bebas asap rokok.

Sejalan dengan hasil Riskesdas (2013), indikator PHBS yang sudah dapat diterapkan sebagian besar rumah tangga di Indonesia yaitu persalinan oleh tenaga kesehatan dan sumber air bersih yang baik dengan persentase lebih dari $80 \%{ }^{6}$. Akan tetapi, indikator lain seperti perilaku tidak merokok dalam rumah, cegah jentik, menimbang balita, dan cuci tangan dengan benar masih berada pada kisaran $47-78 \%{ }^{6}$. 
Penerapan PHBS selanjutnya dikategorikan ke dalam tiga kelompok, yaitu baik, sedang, dan kurang. Penerapan PHBS pada 58,6\% subjek masih tergolong ke dalam kategori kurang. Subjek yang menerapkan PHBS dengan kategori baik hanya berjumlah tiga orang $(4,3 \%)$ dari total subjek. Hasil ini sejalan dengan hasil Riskesdas 2013 yang juga menyatakan bahwa proporsi nasional rumah tangga yang menerapkan seluruh indikator PHBS masih cukup rendah di Indonesia, yaitu sekitar $32,3 \%{ }^{6}$. Hal tersebut menunjukkan bahwa kesadaran penerapan PHBS di rumah tangga masih cukup rendah.

Hasil uji korelasi menunjukkan bahwa tidak ada hubungan yang signifikan antara variabel pola asuh makan dengan tingkat kecukupan zat gizi pada baduta. Hasil penelitian ini sejalan dengan penelitian Quah et al. (2018) yang menemukan bahwa pola pemberian makan pada balita tidak berhubungan dengan asupan zat gizinya ${ }^{19}$. Penelitian tersebut menyimpulkan bahwa praktik pemberian makan yang utama didukung oleh pemodelan asupan makanan oleh ibu kepada anak. Pemodelan asupan makanan yang sehat dibentuk dengan pemberian asupan healthy food lebih tinggi daripada discretionary food kepada anak ${ }^{19}$.

Pola asuh makan yang baik dengan didukung oleh pemilihan jenis makanan yang sehat akan membantu mencukupi asupan zat gizi yang dibutuhkan baduta pada masa golden age. Studi yang dilakukan oleh William et al. (2012) menemukan bahwa terdapat hubungan yang signifikan antara pengetahuan gizi ibu dengan asupan zat gizi ibu namun tidak berhubungan signifikan dengan asupan anak usia sekolah ${ }^{20}$. Dalam studi ini, asupan yang diperoleh baduta masih sangat bergantung pada makanan yang diberikan oleh ibu sehingga memungkinakan adanya keterkaitan antara pengetahuan gizi ibu dengan pemilihan makanan yang

Berdasarkan hasil uji korelasi, ditemukan bahwa perilaku gizi tidak memiliki hubungan yang signifikan dengan status gizi. Hasil ini tidak sejalan dengan penelitian yang dilakukan oleh Kimiywe dan Chege (2015) yang menemukan hubungan signifikan antara perilaku gizi ibu mengenai pemberian MP-ASI pada bayi usia 6-23 bulan dengan status gizinya ${ }^{22}$. Dengan variabel yang sama, penelitian yang dilakukan oleh Palupi et al. (2019) di Sleman, Yogyakarta menemukan hasil bahwa
Studi kualitatif yang dilakukan oleh Akter dan Ali (2014) di Bangladesh menemukan bahwa penerapan sanitasi dan higiene di rumah tangga dipengaruhi oleh banyak faktor, seperti status sosial, budaya tradisional, atau minimnya pengetahuan tentang perilaku hidup bersih dan sehat ${ }^{18}$. Penelitian lain di Kalimantan Selatan juga mengungkapkan bahwa penerapan PHBS pada tatanan rumah tangga dipengaruhi oleh pengetahuan, budaya, sosio-ekonomi, kepercayaan, dan ketersediaan fasilitas atau teknologi ${ }^{3}$.

diberikan ibu kepada anakanya. Sebuah studi di Nigeria mengungkapkan bahwa pengetahuan gizi ibu mengenai pemilihan makanan dan pemberian makan merupakan aspek vital dalam mencapai status gizi baik pada anak ${ }^{21}$. Adanya dukungan pengetahun gizi yang baik pada ibu mengenai pemilihan makanan juga dapat memberikan pengaruh pada asupan zat gizi anaknya.

Penelitian ini menemukan bahwa pola asuh makan yang diterapkan oleh $87,1 \%$ ibu baduta sudah berada dalam kategori baik. Akan tetapi, pola asuh makan yang baik tersebut belum diimbangi dengan adanya pemilihan makanan yang tepat untuk diberikan kepada baduta. Berdasarkan hasil Recall $2 \times 24 h$ dan FFQ ditemukan bahwa ibu masih belum melakukan pemilihan makanan yang tepat untuk baduta dilihat dari jenis dan frekuensi makannya. Beberapa subjek sudah memberikan snack seperti french fries, permen, gorengan (cilok dan cireng), dsb. Hal tersebut tentu dapat mempengaruhi kualitas asupan zat gizi yang diterima oleh baduta. Pemilihan makanan yang diberikan oleh ibu kepada anaknya akan membentuk kebiasaan makan yang pada akhirnya mempengaruhi asupan gizi baduta.

tidak ada hubungan signifikan antara perilaku gizi dengan status gizi berupa indeks BB/U dan TB/U pada balita ${ }^{23}$. Tidak adanya hubungan yang signifikan tersebut diduga karena banyaknya variabel indikator yang digunakan dalam menggambarkan perilaku gizi sehingga ketika diamati hubungannya terhadap status gizi menjadi kurang fokus. Selain itu, status gizi juga cenderung lebih berhubungan dengan asupan dibandingkan dengan perilaku gizi.

Tabel 4 Hasil uji korelasi perilaku gizi dengan status gizi baduta

Status Gizi

\begin{tabular}{|c|c|c|c|c|}
\hline \multirow{3}{*}{ Perilaku Gizi } & \multirow{2}{*}{\multicolumn{2}{|c|}{$\mathrm{BB} / \mathrm{U}$}} & \multirow{2}{*}{\multicolumn{2}{|c|}{$\mathrm{TB} / \mathrm{U}$}} \\
\hline & & & & \\
\hline & $r$ & $p$-value & $r$ & $p$-value \\
\hline Pemberian Imunisasi & 0.057 & 0.641 & -0.136 & 0.267 \\
\hline Inisiasi Menyusui Dini (IMD) & 0.089 & 0.470 & 0.176 & 0.147 \\
\hline Pemberian ASI eksklusif & -1.81 & 0.137 & -0.033 & 0.791 \\
\hline $\begin{array}{l}\text { Pemberian Makanan Pendamping ASI (MP-ASI) } \\
\text { sejak usia } 6 \text { bulan }\end{array}$ & -0.215 & 0.076 & -0.006 & 0.958 \\
\hline Frekuensi mengonsumsi daging dalam satu minggu & -0.141 & 0.249 & -0.025 & 0.839 \\
\hline Frekuensi mengonsumsi telur dalam satu minggu & -0.082 & 0.501 & -0.135 & 0.267 \\
\hline Frekuensi mengonsumsi ikan dalam satu minggu & 0.034 & 0.783 & 0.009 & 0.939 \\
\hline Frekuensi mengonsumsi kacang dalam satu minggu & -0.147 & 0.230 & -0.206 & 0.089 \\
\hline Frekuensi mengonsumsi sayur hijau dalam satu minggu & -0.051 & 0.675 & -0.033 & 0.789 \\
\hline Frekuensi mengonsumsi buah dalam satu minggu & -0.084 & 0.493 & -0.011 & 0.927 \\
\hline
\end{tabular}


Menurut Oh et al. (2019), penerapan perilaku gizi oleh suatu rumah tangga dipengaruhi oleh tingkat pendidikan maternal dan pendapatan ${ }^{24}$. Pendidikan maternal dan status sosio-ekonomi berperan penting dalam pembentukan pengetahuan sikap, dan praktik gizi $^{25}$. Dalam penelitian ini, pengetahuan dan sikap gizi tidak diteliti secara spesifik sehingga perilaku gizi dinilai dari praktik gizi yang dilakukan oleh subjek.

French et al. (2019) menemukan bahwa keluarga dengan pendapatan rendah akan cenderung lebih sedikit mengonsumsi makanan sehat dibandingkan dengan keluarga dengan pendapatan tinggi. Besar kecilnya pendapatan rumah tangga dapat memediasi pola pembelian makan yang nantinya akan menentukan kualitas $^{26}$. Dalam penelitian ini, pengeluaran rumah tangga lebih banyak diperuntukkan memenuhi kebutuhan pangan. Akan tetapi, karena pembelian makanan didominasi oleh kelompok pangan jajanan, kelompok pangan lain yang lebih penting, seperti sumber protein, sayur dan buah, serta susu masih belum menjadi prioritas dalam memenuhi kebutuhan zat gizi anak.

Lambert dan Chivers (2019) dalam studi kualitatif yang dilakukan di Australia mengungkapkan bahwa terdapat beberapa hal yang melatarbelakangi pemilihan makanan oleh individu, baik berupa faktor internal maupun eksternal. Faktor internal biasanya berupa pengetahuan tentang rekomendasi yang benar, pengetahuan tentang ukuran/takaran saji, dan kemampuan mengolah makanan. Di sisi lain, faktor eksternal yang mempengaruhi pemilihan makanan antara lain sumber pengetahuan gizi (misal: media sosial), pengaruh lingkungan, serta waktu, biaya, dan usaha untuk mendapatkan makanan yang dimaksud ${ }^{27}$.

Hasil penelitian ini menunjukkan sebagian besar subjek memiliki perilaku gizi dalam kategori sedang dan kurang. Rendahnya perilaku gizi yang dilakukan oleh ibu dapat dipengaruhi oleh beberapa faktor, diantaranya adalah kondisi fisik atau fisiologis ibu dan bayi, dukungan keluarga, budaya yang dianut (misalnya: tabu makanan), atau informasi yang tidak tepat mengenai makanan dan gizi.
Berdasarkan hasil uji korelasi ditemukan bahwa tidak terdapat hubungan yang signifikan antara PHBS dengan status gizi baduta kecuali untuk variabel lingkungn rumah bebas asap rokok dengan indeks BB/U. Penelitian ini menemukan bahwa kesadaran subjek pada pentingnya pemantauan status gizi baduta masih rendah yang ditandai dengan rendahnya angka penimbangan baduta rutin setiap bulan, yaitu 28,6\%. Berdasarkan Permenkes No.66 tahun 2014, Kemenkes mengamanatkan orang tua yang memiliki anak, khususnya yang masih berusia di bawah dua tahun, untuk setiap bulan datang ke posyandu dengan tujuan memonitoring status gizi dan kesehatan ibu dan bayinya. Penelitian Nurcahyati et al. (2017) yang dilakukan di Kabupaten Cirebon juga menemukan bahwa kesadaran ibu untuk mengikuti program pemantauan di posyandu secara rutin setiap bulan masih cukup rendah, yaitu hanya mencakup setengah dari total subjek ${ }^{28}$. Beberapa penyebab ketidakhadiran ke posyandu antara lain: 1) faktor individu (kesehatan balita, balita menangis, balita sakit) 2) faktor sosial (interaksi antara ibu balita dan petugas kesahatan berupa perasaan tersinggung/perasaan kasihan apabila balita menangis ketika ditimbang), serta 3) faktor komunitas (jarak rumah dengan posyandu). Oleh karena itu, perlu dilakukan revitalisasi posyandu dengan tujuan meningkatkan kesadaran orang tua, khususnya ibu, agar status gizi balita dapat terpantau secara kontinu setiap bulannya.

Dalam penelitian ini, perilaku yang berkaitan dengan kebersihan seperti mencuci tangan sebelum dan sesudah memberikan ASI, setiap keluar dari kamar mandi, dan setiap akan menjamah makanan tidak memiliki hubungan yang signifikan dengan status gizi. Perilaku cuci tangan dikaitkan dengan kejadian infeksi yang dapat tejadi secara fecal-oral. Sebagian besar subjek dalam penelitian ini sudah menerapkan perilaku cuci tangan namun hanya setengah dari total subjek yang mencuci tangannya menggunakan sabun dan air mengalir. Perilaku kebersihan yang tidak tepat dapat meningkatkan risiko terjangkitnya diare akibat infeksi E.Coli yang pada akhirnya dapat mengganggu pertumbuhan linear balita ${ }^{29}$.

Tabel 5 Hasil uji korelasi PHBS dengan status gizi baduta

\begin{tabular}{|c|c|c|c|c|}
\hline \multirow{3}{*}{ Perilaku Hidup Bersih dan Sehat } & \multicolumn{4}{|c|}{ Status Gizi } \\
\hline & \multicolumn{2}{|c|}{$\mathrm{BB} / \mathrm{U}$} & \multicolumn{2}{|c|}{$\mathrm{TB} / \mathrm{U}$} \\
\hline & $r$ & $p$-value & $\mathrm{R}$ & $p$-value \\
\hline *Proses persalinan bayi dibantu oleh tenaga medis & - & - & - & - \\
\hline Melakukan penimbangan berat badan rutin setiap bulan & -0.078 & 0.521 & -0.145 & 0.230 \\
\hline Mencuci tangan sebelum dan sesudah memberikan ASI & -0.031 & 0.799 & 0.006 & 0.960 \\
\hline Selalu mencuci tangan setiap keluar dari kamar mandi & -0.110 & 0.365 & -0.063 & 0.602 \\
\hline Selalu mencuci tangan setiap akan menjamah makanan & -0.069 & 0.571 & -0.026 & 0.834 \\
\hline Selalu mencuci tangan dengan sabun dan air mengalir & -0.053 & 0.664 & 0.035 & 0.772 \\
\hline *Menggunakan air bersih untuk dikonsumsi & - & - & - & - \\
\hline Menggunakan WC laterine di rumah & -0.052 & 0.666 & 0.013 & 0.918 \\
\hline
\end{tabular}




\begin{tabular}{|c|c|c|c|c|}
\hline \multirow{3}{*}{ Perilaku Hidup Bersih dan Sehat } & \multicolumn{4}{|c|}{ Status Gizi } \\
\hline & \multicolumn{2}{|c|}{$\mathrm{BB} / \mathrm{U}$} & \multicolumn{2}{|c|}{$T B / U$} \\
\hline & $r$ & $p$-value & $\mathrm{R}$ & $p$-value \\
\hline Melakukan pembasmian larva nyamuk sekali seminggu & 0.020 & 0.868 & 0.072 & 0.553 \\
\hline Lingkungan rumah bebas dari asap rokok & 0.243 & $* * 0.043$ & 0.097 & 0.423 \\
\hline
\end{tabular}

Hasil uji korelasi variabel prediktor lain, seperti penggunaan WC laterine, pembasmian larva nyamuk seminggu sekali, dan aktivitas fisik rutin, masing-masing tidak memiliki hubungan yang signifikan dengan status gizi. Cakupan masing-masing variabel tersebut juga masih cukup rendah sehingga diperlukan upaya peningkatan dalam edukasi dan status ekonomi untuk dapat mencapai target indikator PHBS dalam tatanan rumah tangga ${ }^{30}$.

Sebuah studi meta-analisis juga membuktikan bahwa intervensi WASH (water, sanitation, and hygiene) berhubungan signifikan dengan peningkatan rata-rata $\mathrm{TB} / \mathrm{U}$ pada balita ${ }^{31}$. Intervensi yang dilakukan berupa salah satu atau kombinasi dari : 1) peningkatan kualitas mikrobiologi air minum; 2) mengurangi kontaminasi fecal-oral baik langsung atau tak langsung; dan 3) promosi kebiasaan cuci tangan setelah defekasi atau sebelum menjamah makanan. Dalam studi tersebut juga dijelaskan bahwa intervensi WASH lebih efektif meningkatkan status gizi anak baduta dibandingkan pada balita. Hal tersebut menunjukkan bahwa masa 1000 HPK (hari pertama kehidupan) merupakan pintu gerbang menuju dunia kanak-kanak. Keterjangkitan terhadap parasit intestinal atau diareal dapat memberikan dampak yang irreversible dan kerusakan jangka panjang pada kesehatan anak ${ }^{31}$.

Gizaw dan Worku (2019) meyimpulkan bahwa gabungan intervensi WASH lebih efektif dibandingkan intervensi tunggal. Hal tersebut menunjukkan bahwa keterpaparan terhadap patogen fecal-oral melalui air minum, sanitasi, dan higiene merupakan interaksi yang kompleks dan berpengaruh satu sama lain. Masingmasing variabel tidak dapat berdiri sendiri dalam rangka pencegahan terhadap penyakit fecal-oral. Diperlukan integrasi seluruh intervensi agar pencegahan infeksi dan pencegahan stunting dapat terlaksana secara efektif ${ }^{32}$.

Penelitian ini menemukan bahwa terdapat hubungan signifikan antara lingkungan rumah bebas asap rokok dengan status gizi $\mathrm{BB} / \mathrm{U}$. Besar $p$-value yang didapat yaitu 0,043 dan koefisien korelasi sebesar 0,243 yang berarti hubungannya bersifat lemah. Hubungan tersebut berarti bahwa lingkungan rumah yang terbebas dari asap rokok dapat memiliki hubungan positif dengan indeks $\mathrm{BB} / \mathrm{U}$ pada baduta. Hasil ini didukung oleh penelitian sebelumnya yang dilakukan oleh Semba et al. (2007) yang menemukan bahwa penggunaan tembakau oleh orang tua dapat menjadi faktor risiko malnutrisi pada anak yang hidup di keluarga miskin di perkotaan Indonesia ${ }^{33}$.

Sementara itu, riset yang dilakukan Husain et al. (2016) berusaha untuk mengetahui hubungan penggunaan tembakau terhadap malnutrisi dilihat dari sudut pandang pengeluaran pangan dan non-pangan suatu rumah tangga. Riset tersebut menemukan bahwa keluarga dengan pengguna tembakau mengalokasikan porsi yang signifikan dari total pengeluaran keluarga digunakan untuk pembelian rokok $^{34}$. Akibatnya, pengeluaran untuk pangan kurang diperhatikan kuantitas dan kualitasnya. Dalam penelitian ini, ditemukan bahwa sebanyak $68,6 \%$ keluarga dari seluruh subjek menggunakan tembakau (menghasilkan asap rokok) di lingkungan rumah. Berkaitan dengan pengeluaran, alokasi untuk pembelian rokok menempati porsi terbesar pada kategori pengeluaran non-pangan. Temuan ini sejalan dengan hasil penelitian Husain et al. (2016) dan Semba et al. (2007) bahwa penggunaan tembakau dalam rumah tangga memilki hubungan signifikan dengan status gizi baduta ${ }^{33,34}$.

\section{KESIMPULAN}

Tidak ditemukan hubungan yang signifikan antara pola asuh makan dengan asupan, perilaku gizi dengan status gizi, dan penerapan PHBS dengan status gizi. Ketidakseimbangan antara pengetahuan dengan faktor sosio-ekonomi penghasilan dapat mengakibatkan terjadinya ketimpangan dalam penerapan pola asuh makan, perilaku gizi, dan PHBS terhadap status gizi baduta. Oleh karena itu, diperlukan sistem monitoring dan evaluasi secara kontinu untuk memastikan bahwa program percepatan stunting yang dijalanakan dapat berjalan secara efektif dan efisien.

\section{ACKNOWLEDGEMENT}

Penulis menyampaikan terima kasih kepada Direktorat Riset dan Pengabdian Masyarakat Direktorat Jenderal Riset dan Pengembangan Kementerian Riset, Teknologi, dan Pendidikan Tinggi dan Lembaga Penelitian dan Pengabdian kepada Masyarakat (LPPM) IPB yang telah memberikan dana hibah untuk pelaksanaan kegiatan Penelitian Terapan Unggulan Perguruan Tinggi (PTUPT) ini. Selain itu, penulis juga menyampaikan terima kasih pihak-pihak yang telah membantu dari mulai pengambilan data hingga penyusunan karya tulis ilmiah ini.

\section{REFERENS}

1. Kementerian Kesehatan Republik Indonesia. Situasi Balita Pendek (Stunting) di Indonesia. Pusat Data dan Informasi, Kementerian Kesehatan Republik Indonesia vol. 12 (2018).

2. Indonesia, K. K. R. Hasil utama Riskesdas 2018. vol. 53 (2013).

3. Arifin, S., Heriyani, F., Rahman, F. \& Anhar, V. Y. Cultural Study on the Behavior of Clean and Healthy in Order of Household in Order to Increase Health Status in South Kalimantan. Asian J. Appl. Sci. 03, 455-464 (2015).

4. Khomsan, A., Dewi, M. \& Ekawidyani, K. R. PENGUATAN POSYANDU MELALUI MODEL EDUKASI 
GIZI. (2019).

5. Lemeshow, Stanleis, Hosmer, David, Klour, Janelle, Lwanga \& Kaggwa, S., W. (World H. O. Besar Sampel dalam Penelitian Kesehatan. (UGM Press, 1997).

6. Dasar, R. K. Penyajian Pokok-Pokok Hasil Riset Kesehatan Dasar 2013. (2013).

7. Hardinsyah, Riyadi H, N. V. Kecukupan energi, protein, lemak, dan karbohidrat. in Widya Karya Pangan dan Gizi (2012).

8. Khomsan, A. Teknik Pengukuran Pengetahuan Gizi. (2000).

9. Kementerian Kesehatan RI. PMK No 2 Tahun 2020 tentang Standar Antropometri Anak. vol. 2011 1-9 (2020).

10. Martianto, D., Riyadi, H. \& Ariefiani, R. POLA ASUH MAKAN PADA RUMAH TANGGA YANG TAHAN DAN TIDAK TAHAN PANGAN SERTA KAITANNYA DENGAN STATUS GIZI ANAK BALITA DI KABUPATEN BANJARNEGARA. J. Gizi dan Pangan 6, 51-58 (2011).

11. Sari, M. R. N. \& Ratnawati, L. Y. Hubungan Pengetahuan Ibu tentang Pola Pemberian Makan dengan Status Gizi Balita di Wilayah Kerja Puskesmas Gapura Kabupaten Sumenep. Amerta Nutr. 2, 182-188 (2018).

12. Widyaningsih, N. N., Kusnandar, K. \& Anantanyu, S. Keragaman pangan, pola asuh makan dan kejadian stunting pada balita usia 24-59 bulan. J. Gizi Indones. 7, 22-29 (2018).

13. Sukandar, D., Khomsan, A., Anwar, F. \& Riyadi, H. Nutrition knowledge, attitude, and practice of mothers and children nutritional status improved after five months nutrition education intervention. ljsbar 23, 424-442 (2015).

14. Blaney, S., Februhartanty, J. \& Sukotjo, S. Feeding practices among Indonesian children above six months of age: A literature review on their potential determinants (part 2). Asia Pac. J. Clin. Nutr. 24, 28-37 (2015).

15. Marotz, L. R. Health, Safety, and Nutrition for the Young Child. (Cengage Learning, 2009).

16. D, S. Fungsi-fungsi Sosio Budaya Makanan. (1991).

17. Beal, T., Tumilowicz, A., Sutrisna, A., Izwardy, D. \& Neufeld, L. M. A review of child stunting determinants in Indonesia. Matern. Child Nutr. 14, 1-10 (2018).

18. Akter, T. \& Ali, A. M. Factors influencing knowledge and practice of hygiene in water, sanitation and hygiene (WASH) programme areas of Bangladesh Rural Advancement Committee. Rural Remote Health 14, 1-10 (2014).

19. Quah, P. L. et al. Maternal feeding practices in relation to dietary intakes and BMI in 5 year-olds in a multi-ethnic Asian population. PLoS One 13, 1-16 (2018).

20. Williams, L., Campbell, K., Abbott, G., Crawford, D. \& Ball, K. Is maternal nutrition knowledge more strongly associated with the diets of mothers or their school-aged children? Public Health Nutr. 15, 1396-1401 (2012).

21. Fadare, O., Amare, M., Mavrotas, G., Akerele, D. \&
Ogunniyi, A. Mother's nutrition-related knowledge and child nutrition outcomes: Empirical evidence from Nigeria. PLoS One 14, 1-17 (2019).

22. Kimiywe, J. \& Chege, P. Complementary feeding practices and nutritional status of children 6-23 months in Kitui County, Kenya. J. Appl. Biosci. 85, 7881-7890 (2015).

23. Palupi, I. R., Susetyowati, S., Meltica, R. \& Farah, F. Feeding Practices and Nutritional Status among Children Under Five Years of Age in Sleman District, Yogyakarta, Indonesia. Pakistan J. Nutr. 18, 888894 (2019).

24. Oh, H. K., Kang, S., Cho, S. H., Ju, Y. J. \& Faye, D. Factors influencing nutritional practices among mothers in Dakar, Senegal. PLoS One 14, 1-14 (2019).

25. Mutalik, A. \& Raje, V. Relationship between maternal education and socioeconomic status on knowledge, attitude and practice of mother and her child regarding acute diarrhoeal diseases. Int. J. Community Med. Public Heal. 4, 4472-4476 (2017).

26. French, S. A., Tangney, C. C., Crane, M. M., Wang, Y. \& Appelhans, B. M. Nutrition quality of food purchases varies by household income: The SHoPPER study. BMC Public Health 19, 1-7 (2019).

27. Lambert, M., Chivers, P. \& Farringdon, F. In their own words: A qualitative study exploring influences on the food choices of university students. Heal. Promot. J. Aust. 30, 66-75 (2019).

28. Permenkes No.66. Pemantauan Pertumbuhan, Perkembangan, dan Gangguan Tumbuh Kembang Anak. Berita Negara Republik Indonesia Tahun 2014 Nomor $1524 \quad$ (2014). doi:10.1017/CBO9781107415324.004.

29. Nurcahyani, L., Hakimi, M. \& Sudargo, T. Efek Pemanfaatan Program Pemantauan Dan Promosi Pertumbuhan Terhadap Status Gizi Balita Di Kota Cirebon. J. Kesehat. Reproduksi 4, 33-49 (2017).

30. Budge, S., Parker, A. H., Hutchings, P. T. \& Garbutt, C. Environmental enteric dysfunction and child stunting. Nutr. Rev. 77, 240-253 (2019).

31. Jayadipraja, E. A., Prasetya, F., Azlimin, A. \& Mando, W. O. S. Y. Family Clean and Healthy Living Behavior and Its Determinant Factors in the Village of Labunia, Regency of Muna, Southeast Sulawesi Province of Indonesia. Public Heal. Indones. 4, 3945 (2018).

32. Gizaw, Z. \& Worku, A. Effects of single and combined water, sanitation and hygiene (WASH) interventions on nutritional status of children: A systematic review and meta-analysis. Ital. J. Pediatr. 45, 1-14 (2019).

33. Semba, R. D. et al. Paternal smoking is associated with increased risk of child malnutrition among poor urban families in Indonesia. Public Health Nutr. 10, 7-15 (2007).

34. Husain, M. J., Virk-Baker, M., Parascandola, M., Khondker, B. H. \& Ahluwalia, I. B. Money Gone Up in Smoke: The Tobacco Use and Malnutrition Nexus in Bangladesh. Ann. Glob. Heal. 82, 749-759.e1 (2016). 